\title{
AUSTRALIA'S CARBON TAX: AN ECONOMIC EVALUATION
}

\author{
Alex Robson
}

\begin{abstract}
Australia's carbon tax has been in place since July 2012. Following the 2013 federal election and change of government, it is likely that the tax will be abolished. This paper evaluates Australia's carbon tax experience and draws lessons for policymakers in the other jurisdictions, who may be considering following the Australian example and implementing their own carbon taxes or cap and trade schemes. Overall, the policy was poorly thought through, badly implemented, and lacked majority public support before it began. Australia's carbon tax experience is an interesting case study in how not to go about implementing climate change policy.
\end{abstract}

JEL codes: H23, Q52, Q54.

Keywords: Australian economic policy; carbon tax; climate change policy.

\section{Introduction}

Australia's carbon tax, which came into effect on 1 July 2012 and is currently set at A \$24.15 (US\$22.00) per tonne of carbon dioxide equivalent $\left(\mathrm{CO}_{2}\right.$-e) emitted, covers a broad range of industry sectors and categories of $\mathrm{CO}_{2}$-e emissions. This paper, which builds upon a number of earlier analyses of Australian climate change policy (see Robson 2007, 2009, 2010), evaluates the carbon tax experience and draws lessons for policymakers around the world who may be considering following the Australian example and implementing their own carbon taxes or cap and trade schemes. ${ }^{1}$

The main effect of Australia's carbon tax has been to significantly increase electricity prices for households and businesses, with no reduction in $\mathrm{CO}_{2}$-e 
emissions. The costs of the tax are expected to increase over time, so that the cumulative costs are expected to be large in relation to Australia's current Gross Domestic Product (GDP). Unfortunately, these costs have never been compared with any benefits that might flow to Australia from the tax. It is well known that an appropriately designed carbon tax which replaces existing costly measures and which is also accompanied by significant reductions in marginal income tax rates may, in theory, have lower economic costs than alternative policy options. However, Australia's tax did not replace the main existing 'complementary' measures (such as Australia’s Renewable Energy Target); indeed, the tax has been accompanied by additional 'non-market' complementary measures. Moreover, there has been no economic 'double dividend' from the carbon tax in the form of lower marginal income tax rates for most Australian workers. Finally, the carbon tax package worsened Australia's budget bottom line. These points are discussed in more detail below.

\section{Overview of the tax}

Australia's carbon tax is a fixed-price emissions-permit system and, at the time of writing, is legislated to move to a 'cap and trade' or flexible emissions price scheme in July 2015. ${ }^{2}$ Although Australia's $\mathrm{CO}_{2}$-e emissions in the electricity sector were expected to fall almost immediately as a result of the carbon tax, the overall purpose of the tax is not to reduce overall emissions below current levels in the short to medium term. The expected effect of the tax is to reduce overall domestic emissions below projected 'business as usual' levels, rather than reducing the absolute level of emissions. Indeed, as Figure 1 shows, overall emissions have risen since the carbon tax was introduced. ${ }^{3}$ The Australian government's own modelling (see Treasury 2011) suggests that with the carbon tax in place, domestic emissions are not expected to stop increasing until 2027, and are not expected to fall below current levels until 2043. 


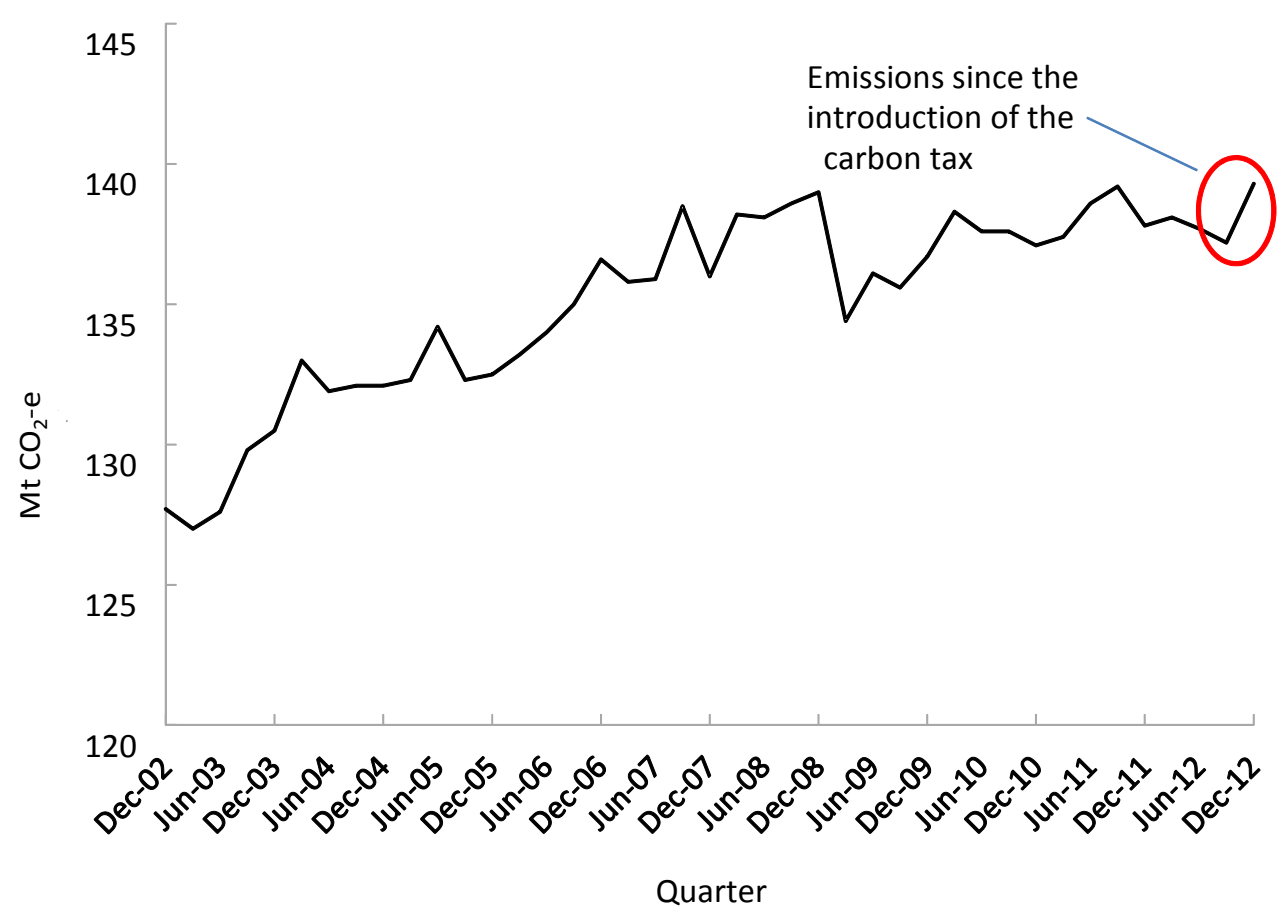

Figure 1: Australia's total CO2-e emissions (megatonnes), seasonally adjusted weather-normalised, 2002-2013.

Source: Department of the Environment (2013).

The government's climate change policy proposed a reduction in emissions of at least 5 per cent compared with 2000 levels by 2020, and a reduction of 80 per cent below 2000 levels by 2050 (see the Department of Climate Change and Energy Efficiency, 2011) It is important to note that these emissions reductions targets do not refer purely to domestic reductions or abatement which actually takes place within Australia's borders. Under the government's carbon tax policy, Australia will reach its overall target only if Australian firms can purchase emissions permits from overseas - in other words, if Australian firms pay businesses in other countries to further reduce their emissions. Under the policy, cumulative abatement relative to business as usual will be 16.7 gigatonnes of CO2-e by 2050. However, 55.7 per cent of this total abatement is sourced from overseas jurisdictions rather than domestically. In other words, a significant part of the policy involves Australian taxpayers paying other countries to reduce their emissions. As a result, along the price path that was 
originally projected by the government, the purchase of foreign permits will involve a cumulative transfer of around A\$75 billion from Australian taxpayers to the rest of the world to 2050 .

The carbon tax applies to emissions of carbon dioxide, methane, nitrous oxide and perfluorocarbons from aluminium smelting. A threshold of 25,000 tonnes of $\mathrm{CO}_{2}$-e applies for determining whether a production facility is covered by the tax. Liable firms which emit but which do not surrender a permit must pay an emissions charge. The sectoral coverage of the Australian scheme is very comprehensive, covering emissions from stationary energy, industrial processes, fugitive emissions (other than from decommissioned coal mines) and emissions from non-legacy waste. The scheme does not cover agricultural and forestry emissions, as well as emissions from the combustion of biofuels and biomass (including $\mathrm{CO}_{2}$-e emissions from combustion of methane from landfill facilities). Household transportation (i.e. fuel for personal vehicle use) is not directly covered by Australia's scheme. ${ }^{4}$ However, the government imposed an effective carbon tax in relation to off-road business use of diesel fuel by reducing the existing diesel fuel tax credit. ${ }^{5}$ The carbon tax is, at the time of writing, due to be extended to the fuel used in trucks on 1 July 2014.

During the 2010 election campaign the Australian government promised that, should it be returned to office, it would not introduce a carbon tax in its next threeyear term. Despite this commitment, the government introduced the tax after the election, even though the Australian public opposed the policy. Not surprisingly, political support for the tax has been weak, so that the policy lacked political robustness and credibility from the outset. For example, a Morgan Poll on 19 July 2011 found that: ${ }^{6}$

- A majority of Australians (62 per cent) agreed that 'The carbon tax will have no significant impact on reducing the total world-wide volume of carbon dioxide put into the atmosphere' (34per cent disagreed).

- An overwhelming majority of Australians (75 per cent) disagreed that 'The \$23 a tonne carbon price should be higher' while only 15 per cent agreed that it should be higher. 
- A majority of Australians agreed that 'We should not have carbon tax until China and the USA have a similar tax.'

- A plurality of Australians (49 per cent) disagreed with the statement that 'The carbon tax is a good first step towards a market-based price on carbon.'

The tax was one of the major policy issues in the federal election of September 2013, and many Australian voters regard the election as a referendum on the tax. Although the newly elected Coalition Government has proposed legislation to abolish the tax, at the time of writing it is unclear whether this will actually become law. As a result, there is a great deal of uncertainty surrounding the future status and design features of the tax. One of the theoretical justifications for introducing a carbon tax is that it provides a credible price signal and encourages future investment in alternative energy sources. With so much uncertainty surrounding current arrangements in Australia, it is doubtful whether the current price signal is very strong.

\section{Economic effects}

\subsection{Electricity prices}

Because the carbon tax has been in place only since July 2012, it is difficult to determine with any great deal of precision its effect on macroeconomic outcomes such as GDP and unemployment. Although unemployment has risen and the Australian government has recently revised down its official forecasts of economic growth over the near term, there is not enough data to sustain a formal statistical analysis of the macroeconomic effects of the tax.

Nevertheless, the tax has generated a number of obvious direct costs. Although the carbon tax directly affects only around 370 Australian businesses, the economic incidence is far broader than the narrow legal incidence. The main way in which domestic businesses have been directly affected by the carbon tax is via increases in energy input costs. In Australia, the manufacturing sector is the main industrial user of electricity, followed by mining. The adverse effects of a carbon tax are therefore directly experienced by electricity-intensive manufacturing activities (such as refining, cement, aluminium, iron and steel production) as well as certain 
types of energy-intensive mining activities (particularly coal mining, but also oil and gas mining).

Survey evidence suggests that many Australian businesses have been unable to pass on the carbon tax-induced energy cost increases, which, according to the Australian Industry Group, have averaged 14.5 per cent for businesses. The Australian Industry Group (2013 a,b) has also published the results of two business surveys demonstrating how the carbon tax has affected input costs and profits. The second survey found that of the three quarters of businesses that were able to estimate how much of their increased costs they were able to pass on to their customers, 70 per cent said they had not been able to pass on any energy cost increases. In other words, in these instances the economic incidence of the carbon tax fell on producers.

The main direct effect of Australia's carbon tax on households has been to significantly increase electricity prices. A number of published estimates indicate that the initial effect of the tax on household electricity prices was at least 10 per cent. For example, the July 2012 press release of the TD Securities Melbourne Institute Monthly Inflation Gauge stated that 'due to the introduction of the carbon tax from 1 July, the price of electricity rose by 14.9 per cent1'. Figure 2 below that the increase in retail electricity prices after the carbon tax was introduced was the highest quarterly increase on record. ${ }^{7}$ 


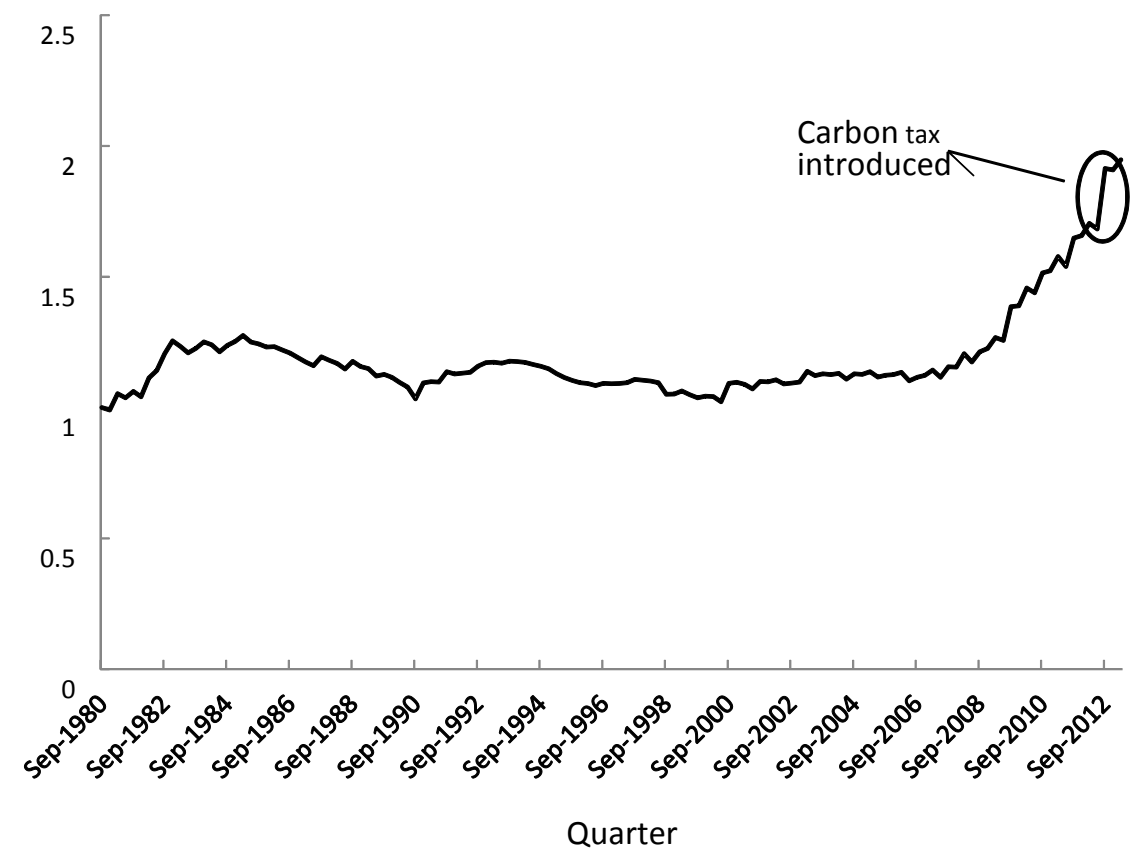

Figure 2: Inflation-adjusted household electricity prices $(1980=1), 1980-2013$.

Sources: Author's calculations; Australian Bureau of Statistics, Cat. No. 6401.0 Consumer Price Index, Australia, Table $7 .^{8}$

In the Australian states of Queensland and New South Wales, the carbon tax, together with other 'green' electricity schemes, now account for up to 19 per cent of a typical household electricity bill.

The Australian government made a number of changes to Australia's personal income tax system in an attempt to compensate some households for increases in the cost of living caused by the carbon tax. However, as discussed below, these tax changes have had negative side effects. In addition, the government allocated free permits to certain emissions-intensive, trade-exposed industries. However, free permits were not made available to non-trade-exposed businesses that were unable to pass on increases in energy inputs.

\subsection{GDP losses}


Although the increase in electricity prices due to the introduction of the carbon tax has been significant, the bulk of the costs of Australia's carbon tax are expected to be incurred over the medium to long term rather than in the short term. Modelling of the economic effects of the carbon tax by the Australian government suggests that the carbon tax will permanently reduce GDP below what it otherwise would have been in every year that it is in place, with these costs growing over time. Although the reductions in annual growth appear to be relatively small when viewed in isolation, the value of the sum of these costs expressed in today's dollars is likely to be significant.

These government modelling exercises, which have been examined in detail elsewhere, ${ }^{9}$ make a number of unrealistic assumptions and as a result are likely to underestimate the costs of Australia's carbon tax. Nevertheless, the Australian Government's modelling output (see Treasury, 2011) can be used to indicate the rough magnitude of the GDP costs of introducing the carbon tax. The models estimate GDP over time with and without the carbon tax, in various policy scenarios out to the year 2050. Two scenarios are particularly relevant: the government's policy, and a 'high price' scenario. The government policy scenario assumes a global target of 550 of $\mathrm{CO}_{2}$-e parts per million (ppm), with an Australian emission target of a 5 per cent cut on 2000 levels by 2020 and an 80 per cent cut by 2050. It also assumes a nominal domestic starting price of A $\$ 23$ in 2012-13, rising at a real rate of 5 per cent per year, before moving to a flexible world price of \$29 in 2015-16. The high price scenario, on the other hand, assumes a global target of $450 \mathrm{ppm}$ world, with an Australian emission target of a 25 per cent cut on 2000 levels by 2020 and an 80 per cent cut by 2050. The starting price is assumed to be $\$ 30$ in 2012-13, again rising at a real rate of 5 per cent, to be around \$61 in 2015-16.

In each scenario GDP is estimated to be lower than it otherwise would have been. As is standard in cost-benefit analysis, the costs of the policy in each scenario can be computed as the discounted present value of the sum of the forgone GDP each year in the future. ${ }^{10}$ The results of these calculations are shown in Figure 3 for various discount rates, which are used to convert the value of a dollar tomorrow to the value of a dollar today so that consistent comparisons can be made. 
There is a well-known debate in the economics literature about the appropriate discount rate to use in cost-benefit analysis. On the one hand, Stern (2007) and Garnaut (2008) use relatively low discount rates, that is, they assume that the value of a dollar tomorrow is very close to its value today. On the other hand, Nordhaus (2007) advocates using a higher, market-based discount rate. ${ }^{11}$ Figure 3 plots the discounted present value of costs relative to Australia's current GDP, using a range of discount rates between 0.5 per cent and 7 per cent. Since the costs of the carbon tax increase over time, choosing a lower discount rate (as advocated by many carbon tax proponents) translates into higher present value of costs.

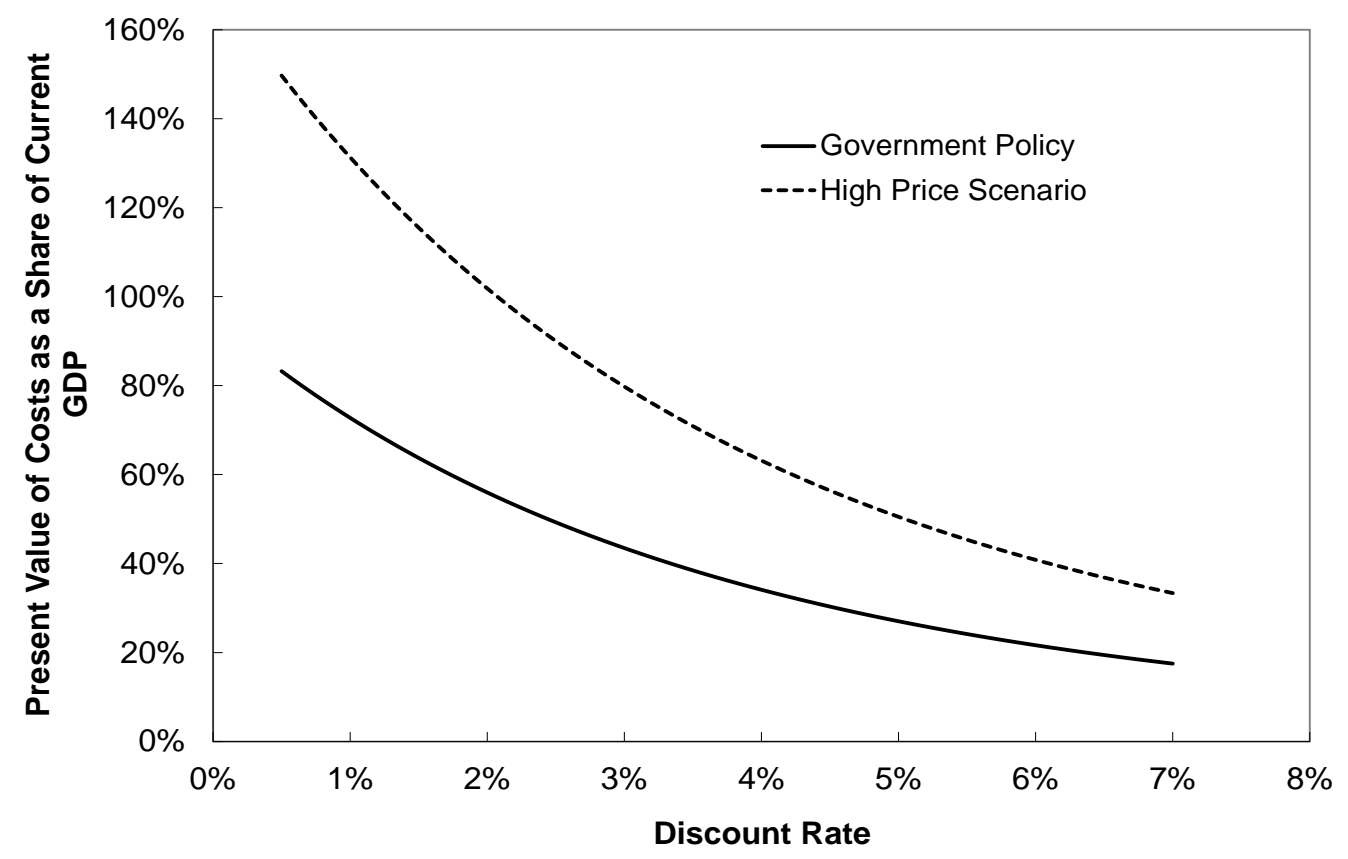

Figure 3: The present value of projected economic costs of Australia’s carbon tax to 2050.

Sources: Treasury (2011); author’s calculations.

The results show that, depending on the discount rate used, the present value of the costs in the government policy scenario could be anywhere between 27 per cent and 83 per cent of current Australian GDP, ${ }^{12}$ or between $\$ 405$ billion and \$1.25 trillion.

\subsection{Complementary measures}


One conventional economic argument for carbon taxes or cap and trade schemes is that introducing a 'market mechanism' will allow other costly schemes (such as renewable energy targets, green subsidies, efficiency standards and other forms of regulation) to be abolished. Proponents argue that since a cap and trade scheme means achieves abatement at least cost, once the emissions or abatement target is fixed under a cap and trade scheme, the existing schemes will not create further emissions reductions (unless the 'cap' is in addition to emissions reductions achieved by these other schemes).

Although this argument is intuitively appealing, there have been a number of practical difficulties with it in Australia's case. First, the Australian Government never actually demonstrated that its favoured market mechanism is, in practice, superior to non-market alternatives. Furthermore, many features of the policies that accompany Australia's carbon tax bear a strong resemblance to command and control policies. Most notably, Australia’s Renewable Energy Target (RET) has remained in place. The RET was implemented in August 2009 well before the carbon tax was introduced, and is an extension of the previous Mandatory Renewable Energy Target (MRET), which began in 2001. The RET requires that by 2020, 20 per cent of Australia’s electricity must come from renewable sources.

Second, the carbon tax legislation introduced new forms of intervention, including the Clean Energy Finance Corporation (CEFC). The CEFC is a wholly government-owned entity that will siphon $\$ 10$ billion of taxpayer funds into renewable energy projects, energy efficiency schemes, and new technologies. The purpose of the CEFC is to provide debt and equity financing to projects which would otherwise not be sufficiently commercial to borrow on their own.

Hence, any hypothetical efficiency gains that may have occurred as a result of eliminating other programs have not materialised. The failure to remove existing 'complementary' policies and the introduction of new instruments has also weakened the intellectual case for adopting so-called market mechanisms.

\subsection{A double dividend?}

Another common argument for introducing a carbon tax (or a cap and trade scheme in which permits are auctioned by the government) is that tax or permit revenues can be 
used to reduce existing distortionary taxes, such as personal income taxes. The 'double dividend hypothesis' refers to the idea that there may actually be two benefits from environmental taxation: the usual welfare gain that a Pigouvian tax brings about by reducing external costs, and an additional gain from the reduction in the welfare losses associated with existing taxes.

Unfortunately, it is unlikely that there has been a double dividend in the case of Australia's carbon tax. As discussed earlier, the introduction of the carbon tax was accompanied by changes to Australia's personal income tax system. Although the Australian Government lowered some average income tax rates, it actually increased marginal tax rates for around 2 million taxpayers (see Table 1). Instead of mitigating the adverse effects of the carbon tax on labour market outcomes, these changes to the personal tax system have likely exacerbated those effects. The increase in marginal tax rates is exactly the opposite policy of what a government would do if it was trying to capture a double dividend from environmental taxation.

Table 1: New statutory income tax rates, old EMTRS and new EMTRs

\begin{tabular}{|c|c|c|c|c|c|}
\hline Income level & $\begin{array}{l}\text { Old } \\
\text { EMTR }\end{array}$ & $\begin{array}{l}\text { New } \\
\text { statutory rate }\end{array}$ & $\begin{array}{l}\text { New } \\
\text { EMTR }\end{array}$ & $\begin{array}{l}\text { Change in } \\
\text { EMTR }\end{array}$ & $\begin{array}{l}\text { Approximate } \\
\text { number of } \\
\text { taxpayers } \\
\text { (million) }\end{array}$ \\
\hline$\$ 0-\$ 16,000$ & 0 & 0 & 0 & No change & 0.28 \\
\hline$\$ 16,001-\$ 18,201$ & 0.15 & 0 & 0 & Fall by 0.15 & 0.28 \\
\hline$\$ 18,201-\$ 20,542$ & 0.15 & 0.19 & 0 & Fall by 0.15 & 0.28 \\
\hline$\$ 20,543-\$ 30,000$ & 0.15 & 0.19 & 0.19 & Rise by 0.04 & 1.38 \\
\hline$\$ 30,001-\$ 37,000$ & 0.19 & 0.19 & 0.19 & No change & 1.19 \\
\hline$\$ 37,001-\$ 67,001$ & 0.34 & 0.325 & 0.34 & No change & 3.58 \\
\hline$\$ 67,001-\$ 80,000$ & 0.3 & 0.325 & 0.325 & Rise by 0.025 & 0.83 \\
\hline$\$ 80,001-\$ 180,000$ & 0.37 & 0.37 & 0.37 & No change & 1.19 \\
\hline$>\$ 180,001$ & 0.45 & 0.45 & 0.45 & No change & 0.18 \\
\hline
\end{tabular}

EMTR, effective marginal tax rate.

Source: Williams (2011).

\subsection{Fiscal effects}


After several years of budget surpluses between 1996 and 2007, Australia's federal government has run budget deficits in each year since 2008, with net government debt increasing from negative \$45 billion to an expected \$219 billion in 2015-16 (see Australian Government, 2013). An important feature of Australia’s fiscal situation in recent years is that revenues from individual taxes, as well as aggregate revenues, have become more difficult to predict.

The carbon tax has two broad effects on the Australian government's budgetary position. On the one hand, the carbon tax is expected to directly raise a substantial amount of revenue. ${ }^{13}$ In addition, the excise rebate reduction - which is an equivalent carbon price applying to business transport emissions from liquid fuels (rail and shipping) and non-transport emissions from businesses using liquid fuels - will also result in higher revenue.

On the other side of the budget, the carbon tax policy involves additional spending and/or tax reductions to compensate some households and selected trade exposed industries, and billions of dollars in other outlays. The carbon tax may also lead to a reduction in company tax revenues and personal income tax revenues below what they otherwise would have been, although this has not been quantified.

Despite raising a large amount of revenue, Figure 4 shows that in its initial years the carbon tax was expected to worsen Australia's budget position, leading to higher deficits and higher public debt than would otherwise have been the case. The cumulative fiscal shortfall was initially expected to be $\$ 4.4$ billion over the period 2011-12 to 2014-15. 


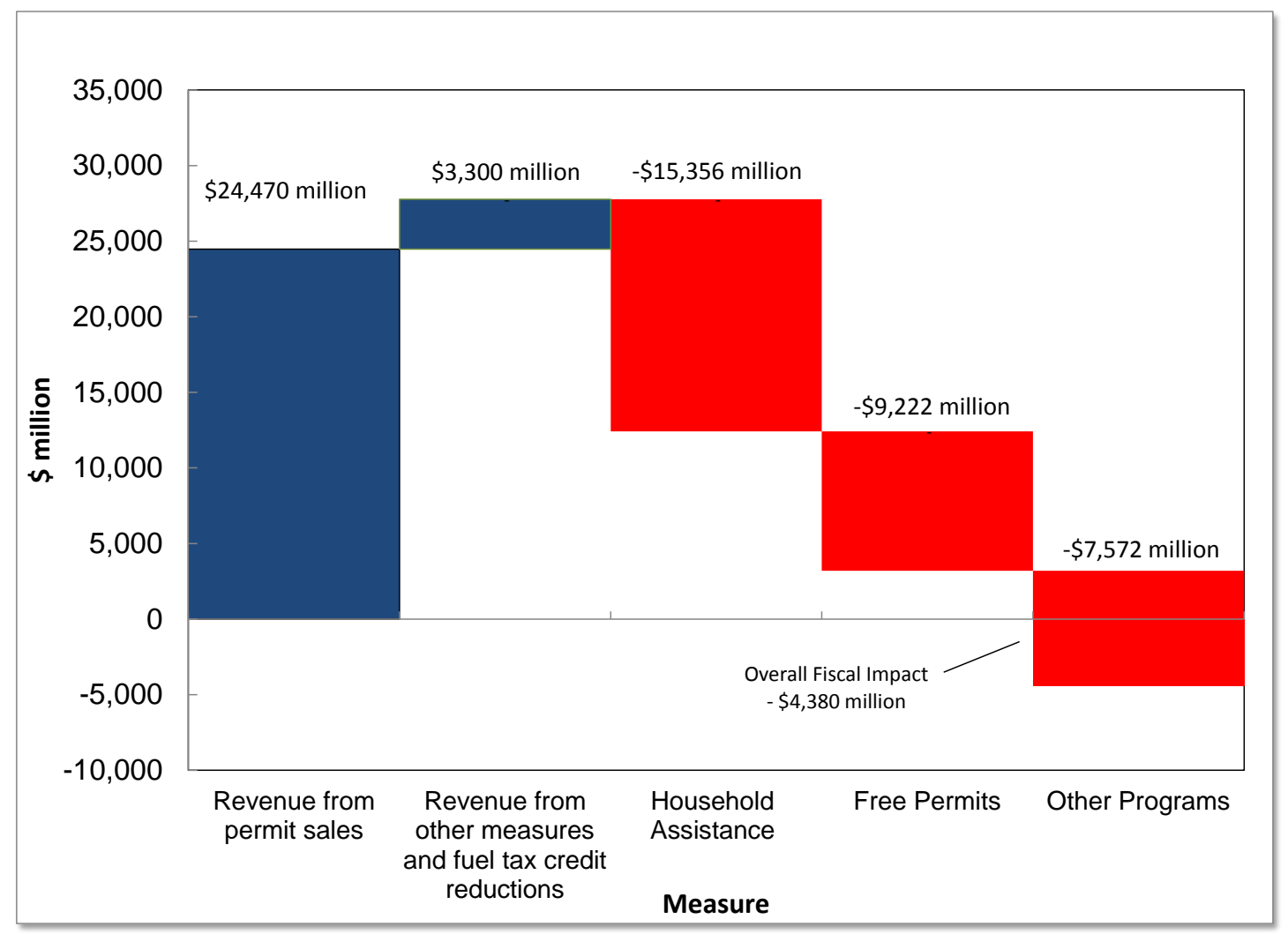

Figure 4: Expected cumulative fiscal impact of the carbon tax and associated policies, 2011-12 to 2014-15.

Source: Department of Climate Change and Energy Efficiency (2011, pp. 131, 135 (Table 1)).

Figure 4 illustrates one of the most significant problems with the design of the overall carbon tax policy: the mismatch between the tax's revenue inflows and the outflows from compensation measures. The changes to the personal income tax system were introduced well before the tax came into effect, and were effectively 'locked in' (although additional tax cuts that were originally promised to come into effect in 2015-16 have since been rescinded). This means that a significant portion of the compensation for the carbon tax was based on assumptions about the uncertain future path of carbon prices. In practice, when the floating price period begins, the carbon tax rate will fluctuate substantially, as will the revenues that the tax raises. 
In other words, the carbon tax has introduced an additional source of uncertainty into the government's budget projections: carbon tax revenues are likely to be relatively volatile, while many of the outlays and compensating tax reductions are difficult to change. The most recent estimates of carbon tax revenue for 2014-15 and 2015-16 are now less than half the original revenue estimates. Should the most recent projections eventuate, there will be a growing negative gap between the revenues generated by the tax and the increases in government spending that have accompanied the scheme.

\section{Conclusions}

Poor policy processes tend to lead to poor policy outcomes. Australia's carbon tax experience is an interesting case study in how not to go about implementing climate change policy. Although a number of Australian reports examined the expected economic costs of the carbon tax, there was never a full cost-benefit analysis of various options. In particular, there was never an assessment of the incremental net benefits to Australia of limiting emissions relative to those of other measures such as adaptation. The debate has been framed as a choice between limiting emissions on the one hand and doing nothing on the other.

Although a number of official reports examined the possible costs of the carbon tax, none of them assessed the incremental net benefits of the policy. Instead, proponents (including many Australian economists) have been content to argue that 'market mechanisms' - that is, cap and trade schemes and carbon taxes - are always superior to direct command and control alternatives. ${ }^{14}$ This argument, while intuitively appealing, ignores the fact that standard textbook results regarding the relative efficiency of taxes, emissions caps and other measures depend on a critical but hidden assumption: taxes or caps must be chosen at some ex ante efficient levels (i.e. where expected marginal benefits equal expected marginal costs).

However, if a carbon tax or an emissions cap diverges from its hypothetical, ex ante efficient level (as is likely in the Australian case), no general conclusions can be drawn regarding the welfare properties of various policy instruments. Standard public choice considerations make it highly unlikely that the textbook assumption holds in reality. In other words, in a world of government and bureaucratic failure, 
the presumed superiority of a market mechanism in which government either determines prices or directly controls the supply side of the market is just that: a presumption.

Unfortunately, in Australia's case there has never been a full assessment of costs and benefits of a carbon tax or a cap and trade scheme, or indeed any demonstration that either policy is better than the other or that either is better than direct command and control alternatives or other policies. Australia's experience demonstrates that in the absence of such evidence the case for a carbon tax is severely - perhaps even fatally - weakened.

\section{References}

Australian Government (2013) Economic Statement, August. Available at http://www.budget.gov.au/2013-

14/content/economic_statement/download/2013_EconomicStatement.pdf (accessed 4 August 2013)

Australian Industry Group (2013a) AI Group Survey: Business Pricing Responses to Australia’s Carbon Tax, the First Six Months. January. Available at http://www.aigroup.com.au/portal/binary/com.epicentric.contentmanagement.s ervlet.ContentDeliveryServlet/LIVE_CONTENT/Publications/Reports/2013/C arbon_price_impacts_Jan_2013.pdf (accessed 15 July 2013).

Australian Industry Group (2013b) Ai Group Survey: Business Picks Up Carbon Tax Bill. June. Available at http://www.aigroup.com.au/portal/binary/com.epicentric.contentmanagement.s ervlet.ContentDeliveryServlet/LIVE_CONTENT/Publications/Reports/2013/C arbon\%2520Tax\%2520report\%2520FINAL.pdf (accessed

Department of Climate Change and Energy Efficiency (2011) Securing a Clean Energy Future: The Australian Government's Climate Change Plan. Available at http://large.stanford.edu/courses/2012/ph240/aslani2/docs/CleanEnergyPlan20120628-3.pdf (accessed 15 July 2013). 
Department of the Environment (2013), Quarterly Update of Australia’s National Greenhouse Gas Inventory, December 2012. Available at http://www.climatechange.gov.au/climate-change/greenhouse-gasmeasurement-and-reporting/tracking-australias-greenhouse-gas-emissio0/quarterly-update-australias-national-greenhouse-gas-inventory-march-13 (accessed 15 July 2013 ).

Department of Finance and Administration (2006) Handbook of Cost-Benefit Analysis. Available at http://www.finance.gov.au/publications/financecirculars/2006/docs/Handbook_of_CB_analysis.pdf (accessed 15 July 2013 ).

Ergas, H. and A. Robson (2012) ‘Modelling as Agit-prop: The Treasury’s Role in Australia’s Carbon Tax Debate’, Agenda 19(2), 9-21.

Garnaut, R. (2008) Garnaut Climate Change Review: Draft Report, June 2008. Available at http://www.garnautreview.org.au/ca25734e0016a131/pages/allreports--resources-draft-report.html (accessed 15 July 2013 ).

Harrison, M. (2010) Valuing the Future: The Social Discount Rate in Cost-Benefit Analysis. Melbourne: Productivity Commission. Available at http://www.pc.gov.au/_data/assets/pdf_file/0012/96699/cost-benefitdiscount.pdf (accessed 15 July 2013).

Nordhaus, W. (2007) 'To Tax or Not to Tax: Alternative Approaches to Slowing Global Warming', Review of Environmental Economics and Policy 1(1), 2644.

Robson, A. (2007) ‘The Prime Ministerial Task Group’s Report on Emissions Trading: A Solution in Search of a Problem', Agenda 14(3), 19-25.

Robson, A. (2009) 'ETS Forum: Why No Cost-Benefit Analysis?' Quadrant Online, 8 August. Available at http://www.quadrant.org.au/blogs/doomedplanet/2009/08/alex-robson (accessed 15 July 2013).

Robson, A. (2010), 'What does the Government’s CPRS Modeling Tell Us?', in A. Moran (ed.), Climate Change: The Facts. Melbourne: Institute of Public Affairs.

Robson, A. (2013) Australia's Carbon Tax: An Economic Evaluation. Washington, DC: Institute for Energy Research. Available at http://www.instituteforenergyresearch.org/wp- 
content/uploads/2013/09/IER_AustraliaCarbonTaxStudy.pdf (accessed 8 September 2013).

Stern, N. (2007) The Economics of Climate Change: The Stern Review. Cambridge: Cambridge University Press.

TD Securities - Melbourne Institute Monthly Inflation Gauge (2012) Press Release, July. Available at http://melbourneinstitute.com/downloads/media_release/2012/TDSec_MI/TDMI_PR_Jul12.pdf (accessed 15 July 2013).

Treasury (2011) Strong Growth, Low Pollution: Modelling a Carbon Price. Available at

http://cache.treasury.gov.au/treasury/carbonpricemodelling/content/report/dow nloads/Modelling_Report_ConsTony Abbott's new direct action scepticsolidated.pdf (accessed 15 July 2013) .

Wade, M. and G. Hutchens (2013) 'Tony Abbott's New Direct Action Sceptics’, Sydney Morning Herald, 28 October. Available at http://www.smh.com.au/federal-politics/political-news/tony-abbotts-newdirect-action-sceptics-20131027-2w9va.html (accessed 28 October 2013 ).

Williams, M. (2011) 'Why Increasing the Tax-Free Threshold is a Bad Idea', IPA Review 63(3), 27-28.

Senior Lecturer in Economics, Griffith University, Australia. Email: a.robson@griffith.edu.au Notes

${ }^{1}$ This paper draws on the author's longer research report on Australia's carbon tax, which was commissioned by the Institute for Energy Research in the United States. (Robson 2013).

2 In 2007, Australia ratified the Kyoto Protocol, which applied to emissions between 2008 and 2012. Australia has also made a 2020 emission reduction pledge under the 
UN Framework on Convention on Climate Change, and intends to join a second commitment period, covering the period 2013-2020. The government implemented the carbon tax as one of the mechanisms to help achieve its 2020 emission reduction pledge.

${ }^{3}$ Note also in Figure 1 that Australia's emissions fell in the first quarter of 2009, corresponding to the economic downturn that was occurring during roughly the same period.

${ }^{4}$ On the other hand, refineries are covered by the scheme, and hence petrol prices are indirectly affected by the scheme.

${ }^{5}$ The purpose of the diesel fuel tax credit scheme is to remove the effect of fuel tax on off-road business inputs to ensure that production decisions are not distorted either within an industry or across industries.

${ }^{6}$ See http://www.roymorgan.com/findings/finding-4687-201302150042 (accessed 15 July 2013).

${ }^{7}$ Note also from Figure 2 that household electricity prices have been rising steadily in Australia since 2008. This increase is due to a number of regulatory changes in the sector, which have affected network (transmission and distribution) costs, as well as increases in the costs of other 'green' schemes.

${ }^{8}$ Available at http://www.abs.gov.au/AUSSTATS/abs@.nsf/DetailsPage/6401.0Sep\%202013?Open Document (accessed 25 July 2013) .

${ }^{9}$ See, for example, Ergas and Robson (2012).

10 This methodology is standard. For example, the Australian Government’s Handbook of Cost-Benefit Analysis states that: 'a project should be accepted if the sum of its discounted benefits exceeds the sum of its discounted costs; that is, where its net present value exceeds zero' (Department of Finance and Administration 2006, p. 62). 
${ }^{11}$ See Harrison (2010) for an excellent analysis of the issues surrounding the appropriate choice of the social discount rate.

${ }^{12}$ Australia’s GDP in the year to March 2013 was \$1.5 trillion. See Australian Bureau of Statistics, Cat. No. 5206.0, Australian National Accounts: National Income, Expenditure and Product. Available at http://www.abs.gov.au/ausstats/abs@.nsf/mf/5206.0 (accessed 15 July 2013).

13 The government's 2013-14 Budget estimated that the tax would raise over \$35 billion in the first five years of the scheme, which is around 2 per cent of anticipated tax revenues over the same period.

${ }^{14}$ One leading Australian private sector economist even recently claimed that any economist who did not opt for emissions trading 'should hand his degree back' (Wade and Hutchens 2013). 